\title{
Pengaruh Koneksi Politik, Capital Intensity, Profitabilitas, Leverage dan Ukuran Perusahaan Pada Agresivitas Pajak
}

\author{
Kadek Ayu Windaswari ${ }^{1}$ \\ Ni Ketut Lely Aryani Merkusiwati ${ }^{2}$ \\ ${ }^{1}$ Fakultas Ekonomi dan Bisnis Universitas Udayana (Unud), Bali, Indonesia \\ email: ayuwinda28@gmail.com/Telp: +6285739783520 \\ ${ }^{2}$ Fakultas Ekonomi dan Bisnis Universitas Udayana (Unud), Bali, Indonesia
}

\begin{abstract}
ABSTRAK
Tindakan perencanaan pajak baik menggunakan cara yang tergolong legal (tax avoidance) atau ilegal (tax evasion) dengan tujuan untuk mengurangi beban pajak disebut agresivitas pajak. Tujuan dari penelitian ini adalah untuk menganalisis pengaruh koneksi politik, capital intensity, profitabilitas, leverage, dan ukuran perusahaan pada agresivitas pajak. Objek penelitian ini yaitu perusahaan sektor pertambangan yang terdaftar di Bursa Efek Indonesia periode tahun 2012-2016. Sampel diperoleh sebanyak 60 perusahaan dengan metode purposive sampling selama periode 5 tahun. Teknik analisis data pada penelitian ini yaitu analisis regresi linear berganda.Hasil analisis menemukan bahwa profitabilitas berpengaruh negatif pada agresivitas pajak. Variabel koneksi politik, capital intensity, leverage, dan ukuran perusahaan tidak berpengaruh pada agresivitas pajak.
\end{abstract}

Kata kunci: Agresivitas pajak, capital intensity, koneksi politik, leverage, profitabilitas, ukuran perusahaan.

\begin{abstract}
Tax planning measures either use legal (tax avoidance) or illegal (tax evasion) for the purpose of reduce the tax burden is called tax aggressiveness. The purpose of this study was to analyze the influence of political connections, capital intensity, profitability, leverage, and firm size on tax aggressiveness. The object of this research is the mining sector companies listed on the Indonesia Stock Exchange period 2012-2016. Samples obtained as many as 60 companies by purposive sampling method during the period of 5 years. Data analysis technique used in this research is multiple linear regression analysis. The results of the analysis found that profitability had a negative effect on tax aggressiveness. Variables of political connection, capital intensity, leverage, and firm size have no effect on tax aggressiveness.

Keywords: Capital intensity, leverage,political connections, profitability, firm size, tax aggressiveness.
\end{abstract}

\section{PENDAHULUAN}

Pajak merupakan sumber penerimaan negara yang paling potensial dan menempati persentase tertinggi dalam APBN apabila dibandingkan dengan penerimaan lainnya. Berdasarkan data APBN yang dipublikasikan oleh 
Kementerian Keuangan Republik Indonesia, besarnya target dan realisasi penerimaan pajak pada Tahun 2012-2016, disajikan dalam Tabel 1 berikut.

Tabel 1.

Target dan Realisasi dari Penerimaan Pajak Tahun 2012 - 2016

(dalam Triliun Rupiah)

\begin{tabular}{clll}
\hline Tahun & $\begin{array}{l}\text { Target } \\
\text { Penerimaan }\end{array}$ & $\begin{array}{l}\text { Realisasi } \\
\text { Penerimaan }\end{array}$ & $\begin{array}{l}\text { Persentase } \\
\text { Penerimaan }\end{array}$ \\
\hline 2012 & 885,02 & 835,25 & $94,4 \%$ \\
2013 & $1.148,4$ & $1.071,7$ & $93,3 \%$ \\
2014 & $1.246,1$ & $1.143,3$ & $91,7 \%$ \\
2015 & $1.489,3$ & $1.235,8$ & $83 \%$ \\
2016 & $1.539,2$ & $1.283,6$ & $83,4 \%$ \\
\hline \multicolumn{2}{l}{ Sumber $:$ Kementerian Keuangan Republik Indonesia, diolah 2017 }
\end{tabular}

Berdasarkan Tabel 1 di atas, terlihat bahwa realisasi penerimaan negara yang bersumber dari pajak di Indonesia belum mencapai target yang telah ditetapkan dan mengalami fluktuasi. Persentase realisasi penerimaan pajak dari tahun 2012sampai tahun 2015 terus mengalami penurunan. Pada tahun 2015 ke tahun 2016 mengalami peningkatan sebesar 0,4\%. Pada laporan Biro Analisa Anggaran dan Pelaksanaan APBN yang dipublikasikan oleh website Dewan Perwakilan Rakyat Republik Indonesia (2013) menyatakan bahwa tidak tercapainya target penerimaan Negara dikarenakan adanya penurunan tarif pajak, pemberian intensif pajak yang tidak tepat sasaran, rendahnya kesadaran masyarakat dalam membayar pajak, tingginya praktik penghindaran pajak (tax avoidance) dan penggelapan pajak (tax evasion) oleh wajib pajak badan dan pribadi, rendahnya integritas para pegawai pajak dan adanya tekanan dari ekonomi global.

Mardiasmo (2016:10) mengungkapkan bahwahambatan-hambatan yang dihadapi oleh Ditjen pajak dalam melakukan pemungutan pajak disebabkan karena adanya perlawanan dari Wajib pajak, perlawanan tersebut dibedakan 
menjadi dua meliputi perlawanan pasif dilakukan karena masyarakat enggan untuk membayar pajak, yang diakibatkan oleh perkembangan intelektual dan moral, sistem perpajakan yang sulit dipahami masyarakat, tidak dilaksanakannya sistem kontrol dengan baik. Perlawanan aktif meliputi semua usaha dan tindakan yang dilakukan oleh Wajib Pajak yang bertujuan untuk menghindari pajak meliputi tax avoidance merupakan usaha untuk mengurunkan beban pajak dengan tidak melanggar undang-undang. Tax evasion merupakan usaha menurunkan beban pajak dengan melanggar undang-undang yakni menggelapkan pajak.

Bagi negara, pajak merupakan salah satu sumber penerimaan penting yang digunakan untuk membiayai pengeluaran negara, baik untuk pengeluaran rutin maupun pengeluaran pembangunan. Berbeda denganperusahaan yang mengganggap bahwa pajak merupakan beban yang akan mengurangi laba bersih (Suandy, 2011:1). Hal tersebut menyebabkan perusahaan menjadi agresif dalam perpajakan dan mencari cara untuk mengurangi beban pajak. Tindakan merekayasa pendapatan kena pajak yang dirancang melalui perencanaan pajak dengan menggunakan cara secara legal (tax avoidance) ataupun ilegal (tax evasion)disebut sebagai agresivitas pajak (Frank et al.,2009).

Sektor yang kerap melakukan tindakan agresivitas pajaksalah satunya yaitu sektor pertambangan. Pada tahun 2009 kasus agresivitas pajak dilakukan oleh pada perusahaan tambang besar yaitu BUMI Resources, Kaltim Coal (KPC) dan Arutmin, diindikasi telah melakukan praktik penghindaran pajak senilai Rp.2,176 Triliun, diantaranya yaitu KPC sebagai penghindar pajak terbesar senilai 
Rp. 1,5 Triliun, kemudian BUMI Resources yakni senilai Rp. 376 Miliyar serta Arutmin senilai Rp. 300 Miliyar (Dewi dan Krisna, 2017).

Kementerian Keuangan Repulik Indonesia (Kemenkeu, 2016)menyatakan bahwa Pemerintah menyoroti tingkat kepatuhan wajib pajak di bidang pertambangan mineral dan batu bara serta minyak dan gas bumi yang masih rendah. Pada tahun 2015, misalnya, pengusaha minerba yang melaporkan Surat Pemberitahuan (SPT) Tahunan tercatat sebanyak 2.557, sedangkan yang tidak melaporkan mencapai 3.624. Data Direktorat Jenderal Pajak (DJP) Kementerian Keuangan menunjukkan, dari total 6.001 wajib pajak mineral dan batubara, hanya 967 wajib pajak yang menjadi peserta program Amnesti Pajak dengan uang tebusan paling rendah yang dibayarkan oleh wajib pajak minerba tercatat sebesar Rp5 ribu, dan tertinggi Rp96,3 miliar. Wajib pajak pertambangan minyak dan gas bumi, totalnya 1.114 wajib pajak, hanya 68 yang menjadi peserta Amnesti Pajak dengan uang tebusan paling rendah yang dibayarkan oleh wajib pajak minerba tercatat sebesar Rp150 ribu, dan tertinggi Rp17,4 miliar (Kemenkeu.go.id, 2016). Hal ini memperlihatkan bahwa tingkat kepatuhan pajak perusahaan-perusahaan pertambangannya khususnya minerba dan migas masih sangat memprihatinkan, sehingga rendahnya kepatuhan pajak mengindikasikan adanya keinginan untuk melakukan tindakan agresivitas pajak.

Beberapa variabel yang akan diteliti karena berdasarkan penelitianpenelitian sebelumnya diindikasikan memengaruhi agresivitas pajak yaitu koneksi politik, capital intensity, profitabilitas, leverage dan ukuran perusahaan. Faktor pertama yaitu koneksi politik. Leuz dan Gee (2006) berpendapat bahwa 
perusahaan harus memanfaatkan dan mencari peluang di dalam lingkungan bisnis untuk menyusun strategi bersaing, salah satu peluang tersebut yaitu melalui koneksi politik. Faccio (2010) menemukan bahwa perusahaan yang berkoneksi politik memunyai leverage yang lebih tinggi, membayar pajak lebih rendah, serta memiliki kekuatan pasaryang lebih kuat. Faccio (2010) juga menemukan bahwa di negara-negara yang memiliki koneksi politik ditandai dengan tingginya tingkat korupsi dibandingkan dengan negara yang tidak memiliki koneksi politik.

Faktor kedua dalam penelitian ini yaitu capital intensity. Capital intensity jugadiduga memiliki pengaruh pada agresivitas pajak. Berdasarkan Penelitian Andhari dan Sukartha (2017) membuktikan capital intensity berpengaruh positif pada agresivitas pajak perusahaan .Adanya perbedaan dalam penyusutan aset antara perhitungan akuntansi dan perhitungan pajak menjadi modus bagi perusahaan untuk menekan beban pajak.Rodriguez dan Arias (2012) mengungkapkan bahwaperusahaan akan memanfaatkan aset tetap perusahaan untuk mengurangi bebanpajak hal ini dikarenakan adanya penyusutan aset tetap perusahaan setiap tahunnya.

Faktor ketiga dalam penelitian ini yaitu profitabilitas. Faktor ini dianggap memengaruhi tindakan agresivitas pajakkarena semakin tinggi laba yang dapat dihasilkan oleh perusahaan maka semakin tinggi beban pajak perusahaan.semakin tingginya profitabilitas perusahaan akan memengaruhi tindakan yang akan diambil oleh perusahaan terkait dengan beban pajak yang akan dibayarkan. Hasil penelitian dari Rodriguez dan Arias (2012) membuktikan bahwa variabel profitabilitas berpengaruh terhadap ETR. 
Faktor keempat dalam penelitian ini yaitu leverage. Indikasi tindakan agresivitas pajak yang dilakukan perusahaan diduga melalui kebijakan pendanaan yang akandiambil perusahaan. Kebijakan pendanaan tersebut salah satunya yaituleverage. Perusahaan memilih menggunakan leverage untuk membiayai operasional perusahaan juga diduga akan memengaruhi pajak yang akan dibayarkan. Semakin besar penggunaan leverage dalam kegiatan operasional perusahaan akan menambah beban bunga yang akan dibayar oleh perusahaan sehingga mengurangi beban pajak perusahaan. Richardson dan Lanis (2007) menemukan bahwa semakin tingginya utang perusahaan maka nilai ETR perusahaan akanmenjadi semakin rendah.

Faktor kelima dalam penelitian ini yaitu ukuran perusahaan. Ukuran perusahaan juga memengaruhi perusahaan dalam membayar pajak karena besar kecilnya suatu perusahaan akan memengaruhi pendapatan perusahaan tersebut, karena memeroleh laba maka akan memengaruhi aset perusahaan dan tingkat utang perusahaan yang berpengaruh terhadap pembayaran pajak (Ardyansah dan Zulaikha, 2014). Hasil penelitian Ardyansah dan Zulaikha (2014) membuktikan bahwa ukuran perusahaan memiliki pengaruh yang signifikan terhadap tingkat agresivitas pajak perusahaan.

Penelitian ini dilakukan dengan mengambil sampel pada perusahaan sektor pertambangan di Bursa Efek Indonesia periode 2012-2016. Sektor pertambangan merupakan salah satu perusahaan yang tingkat kepatuhan pajaknya masih tergolong rendah. Perusahaan sektor pertambangan juga ingin diteliti karena merupakan kelompok industri high profile, yang dalam operasionalnya 
bersinggungan langsung dengan kepentingan luas sehingga pasti akan menjadi perhatian bagi pemerintah, investor maupun masyarakat dalam ketaatannya membayar pajak. Penelitian ini dilakukan dengan tujuan untuk menganalisis mengenai pengaruh koneksi politik, capital intensity, profitabilitas, leverage, dan ukuran perusahaan pada agresivitas pajak.

Manfaat dari penelitian ini yakni pertama, manfaat teoretis yaitu diharapkan dapat memberikan pengembangan pengetahuan dalam bidang ilmu akuntansi yang berkaitan dengan pengaruh koneksi politik, capital intensity, profitabilitas, leverage dan ukuran perusahaan pada agresivitas pajak. Penelitian ini juga diharapkan dapat menjadi sebuah referensi bagi penelitian berikutnya mengenai agresivitas pajak. Kedua, manfaat praktis yaitu diharapkan dapat bermanfaat untuk menambah wawasan dan digunakan sebagai pertimbangan ataupun masukan bagi pemerintah dalam mengambil keputusan-keputusan ekonomi serta sebagai pandangan dalam pengambilan kebijakan pajak dan mengatasi kelemahan-kelemahan perpajakan dimasa yang akan datang. Bagi investor hasil penelitian ini diharapkan dapat bermanfaat sebagai pertimbangan untuk mengambil keputusan dalam berinvestasi.

Teori stakeholder mengungkapkan bahwa ketika perusahaan melakukan kegiatan operasionalnya maka perusahaan harus memertimbangkan kepentingan semua pihak yang akan terlibat dalam aktivitas operasi tersebut. Perusahaan harus memerhatikan kepentingan semua pihak termasuk di dalamnya yaitu shareholder maupun masyarakat, pemerintah, pihak supplier, konsumen dan lainnya (Chairiri, 2008). Inti keseluruhan teori stakeholder terletak pada apa yang akan terjadi 
ketika perusahaan dan stakeholder menjalankan hubungan mereka (Fatayatiningrum, 2011).Untuk meningkatkan eksistensinya, perusahaan memerlukan dukungan stakeholder sehingga aktivitas perusahaan harus mempertimbangkan persetujuan dari stakeholder. Semakin kuat stakeholder, maka perusahaan harus semakin beradaptasi dan memperhatikan stakeholder(D. Putri, 2016). Rahayu dan Jaka (2017) berpendapat bahwa kinerja suatu perusahaan dianggap baik apabila mampu mendapatkan laba yang tinggi. Untuk memeroleh laba perusahaan yang tinggi maka perusahaan akanmeminimalkan beban-beban yang harus ditanggung oleh perusahaan salah satunya yaitu beban pajak. Di kalangan perusahaan-perusahaan besar tindakan agresivitas pajak sering terjadi, terutama di Indonesia.

Teori akuntansi positif merupakan teori yang dicetuskan oleh Watts dan Zimmerman pada tahun 1986. Teori akuntansi positif mencoba untuk memahami dan memprediksi pilihan kebijakan akuntansi yang akan ditetapkan oleh perusahaan (Watts dan Zimmerman, 1990). Tiga hipotesis utama dalam teori akuntansi positif yakni the bonus plan hypothesis yaitu perusahaan yang memiliki rencana pemberian bonus, manajer perusahaan akan termotivasi oleh perolehan bonus sehingga manajer akan menggunakan metode-metode akuntansi untuk memainkan besar kecilnya angka-angka akuntansi pada laporan keuangan. The debt covenant hypothesis menyatakan bahwa untuk menghindari terjadinya perjanjian utang saat perusahaan mulai merasa terancam melanggar perjanjian utang maka manajer perusahaan akan memilih metode akuntansi yang dapat menaikkan pendapatan atau laba. The political cost hypothesis, hipotesis ini 
memprediksi bahwa perusahaan yang besar akan menggunakan metode akuntansi yang cenderung mengurangi laba yang akan dilaporkan untuk meminimalkan biaya politik yang harus ditanggung perusahaan.

Teori sinyal memberi pemahaman mengenai pentingnya suatu informasi yang perusahaan miliki. Informasi terkait perusahaan akan digunakan oleh pihakpihak berkepentingan untuk menilai keadaan perusahaan di masa lalu, saat ini, maupun prediksi untuk masa depan (Lesmana, 2016). Pemberian sinyal dilakukan oleh manajer untuk mengurangi asimetri informasi diantara pihak perusahaan dengan pihak luar (investor, pemerintah, dan kreditur). Informasi yang dikeluarkan perusahaan yang dapat menjadi sinyal baik bagi pihak luar perusahaan terutama investor yaitu annual report.

Perusahaan yang berkoneksi politik merupakan perusahaan yang melalui cara-cara tertentu mengusahakan adanya kedekatan dan memunyai ikatan secara politik dengan para politisi atau pemerintah (Purwoto, 2011). Keberadaan suatu perusahaan sangat dipengaruhi oleh dukungan yang diberikan oleh stakeholder perusahaan tersebut (Mustika, dkk. 2017). Hubungan antara perusahaan sebagai pemilik dengan pemerintah sebagai pemegang saham dominan dimanfaatkan oleh pihak perusahaan untuk melakukan tindakan perencanaan pajak karena perusahaan yang berkoneksi politik diindikasikan adanya perlakuan yang istimewa dari pemerintah sehingga mengakibatkan menurunnya transparansi pada laporan keuangan perusahaan.

Kim dan Zhang (2013) dalam penelitiannya terkait pengaruh koneksi politik terhadap tindakan pajak agresif. Hasil penelitiannya menunjukkan bahwa 
perusahaan yang mempunyai koneksi politik lebih melakukan agresivitas pajak dibandingkan dengan perusahaan yang tidak mempunyai koneksi politik. Chaney et al. (2007), menemukan bahwa perusahaan yang memiliki koneksi politik secara signifikan memiliki kualitas laba dalam laporan keuanganlebih buruk apabila dibandingkan dengan perusahaan yang tidak berkoneksi politikkarena hubungan politik yang dimilikinya mampu menghilangkan atau mengurangi konsekuensi negatif yang ada.Berdasarkan uraian tersebut maka hipotesis penelitian ini yaitu $\mathrm{H}_{1} \quad$ :Koneksi politik berpengaruh positif pada agresivitas pajak.

Capital intensityadalah aktivitas investasi perusahaan dengan investasi dalam bentuk aset tetap (intensitas modal) dan persediaan (intensitas persediaan).Capital intensity dalam penelitian ini digunakan untuk mengukur investasi perusahaan dalam bentuk aset tetap. Aset tetap meliputi tanah, bangunan, pabrik, peralatan, mesin, kapal, kendaraan bermotor, pesawat udara dan property. Teoristakeholder memfokuskan tentang bagaimana perusahaan mengawasi dan merespon kebutuhan para stakeholdersnya (Siregar dan Dini, 2016). Hal ini membuat perusahaan berusaha untuk menunjukkan bahwa perusahaan memiliki laba yang stabil. Perusahaan akan melakukan perencanaan pajak dengan meningkatkan investasi asetnya agar dapat menekan beban pajak yang akan dibayarkan demi meningkatkan laba bersih yang diperoleh. Hasil penelitian Andhari dan Sukartha (2017) membuktikan capital intensity berpengaruh positif pada agresivitas pajak perusahaan. Perusahaan akan semakin agresif terhadap kewajiban perpajakannya ketika capital intensity perusahaan juga meningkat.Berdasarkan uraian tersebut maka hipotesis penelitian ini yaitu 
$\mathrm{H}_{2} \quad$ :Capital intensity berpengaruh positif pada agresivitas pajak.

Profitabilitas merupakan kemampuan perusahaan memeroleh laba dalam hubungannya dengan penjualan, total aktiva maupun modal sendiri (Sartono, 2010:122). Untuk mengukur kinerja manajemen dalam mengelola perusahaan, para stakeholder akan menjadikan laba sebagai indikator.Perusahaan dengan nilai profitabilitas yang bagus diasumsikan tidakakan melakukan tindakan agresivitas pajakkarena pertimbangan citra perusahaan akan menjadi buruk apabila perusahaan melalukan praktik tersebut. Hasil penelitian yang mendukung hipotesis penelitian ini yaitu penelitian Rodriguez dan Arias (2012), Utari dan Supadmi (2017) serta Ariawan dan Setiawan (2017) membuktikan bahwa profitabilitas berpengaruh negatif terhadap agresivitas pajak. Berdasarkan uraian di atas maka hipotesis penelitian ini yaitu $\mathrm{H}_{3}$ : Profitabilitas berpengaruh negatif pada agresivitas pajak.

Leverage adalah kemampuan perusahaan untuk memenuhi kewajiban finansialnya baik dalam jangka pendek maupun jangka panjang, atau mengukur sejauh mana perusahaan dibiayai dengan utang (Wiagustini, 2014:85).Stakeholder merupakan pihak-pihak yang berkepentingan baik secara langsung maupun tidak langsung, terhadap eksistensi atau aktivitas perusahaan (Siregar dan Dini, 2016). Perusahaan yang menggunakan leverage dalam operasionalnya akan berusaha untuk menjaga labanya demi keberlangsungan dengan pihak kreditur yang juga salah satunya mewakili stakeholder. Perusahaan yang tingkat leveragenya tinggi maka terikat dengan kepentingan kreditur untuk tetap memertahankan laba perusahaan dalam kondisi stabil sehingga tidak agresif dalam hal perpajakan. 
Apabila perusahaan berusaha untuk meningkatkanlaba, maka beban pajak yang dibayarkan juga akan meningkat (Adisamartha danNaniek, 2015).

Hipotesis debt covenantmenyatakan semakin tinggi hubungan perusahaan dengan kreditur akan membuat perusahaan berusaha memertahankan laba periode berjalan agar tetap stabil untuk menjaga stabilitas kinerja perusahaan yang terlihat melalui laba, semakin tingginya kepentingan perusahaan dengan kreditur maka kreditur akan mengawasi perusahaan demi kelangsungan pinjaman modaleksternal (Gemilang, 2017).Teori sinyal juga menyatakan bahwa penggunaan utang merupakan sinyal positif, dengan harapan bahwa kreditur akan menangkap sinyal tersebut dan menunjukkan bahwa perusahaan memiliki prospek yang bagus, sehingga kreditur bersedia untuk memberikan pinjaman dana. Penelitian Andhari dan Sukartha (2017) membuktikan bahwa leverage berpengaruh negatif pada agresivitas pajak.Berdasarkan uraian tersebut maka dirumuskan hipotesis penelitian yaitu $\mathrm{H}_{4}$ : Leverage berpengaruh negatif pada agresivitas pajak.

Ukuran perusahaan yaitu skala yang diklasifikasikan menjadi besar ataupun kecilnya perusahaan menurut berbagai cara meliputi: total aktiva, kapitalisasi pasar, penjualan dan lainnya (Hasibuan, 2009). Hipotesis biaya politik memprediksi bahwa perusahaan yang besar akan menggunakan metode akuntansi yang cenderung untuk mengurangi laba yang akan dilaporkan dengan tujuan untuk meminimalisasi biaya politik yang harus ditanggung. Stakeholder dapat mengendalikan dan memengaruhi pemakaian sumber-sumber ekonomi yang digunakan perusahaan, sehingga ukuran perusahaan akan memengaruhi tindakan 
agresivitas pajak yang dilakukan oleh perusahaan. Semakin besar ukuran perusahaan dimungkinkan bahwa perusahaan memiliki relasi dengan pihak luar lebih banyak dibandingkan perusahaan kecil, hal ini akan memudahkan perusahaan untuk melakukan perencanaan pajak guna untuk meminimalkan beban pajak perusahaan.Richardson dan Lanis (2007) berpendapat bahwa semakin rendah effective tax rate (ETR) yang dimiliki perusahaan maka semakin besar ukuran suatu perusahaan tersebut. Penelitian Putra dan Lely (2016) menemukan bahwa ukuran perusahaan berpengaruh positif dan signifikan terhadap agresivitas pajak yang diproksikan dengan tax avoidance. Berdasarkan uraian tersebut maka dirumuskan hipotesis penelitian yaitu $\mathrm{H}_{5}$ : Ukuran perusahaan berpengaruh positif pada agresivitas pajak.

\section{METODE PENELITIAN}

Jenis penelitian yang digunakan dalam penelitian ini adalah asosiatif dengan menggunakan pendekatan kuantitatif. Objek penelitian ini yaitu perusahaan sektor pertambangan yang terdaftar di Bursa Efek Indonesia periode tahun 20122016 (5 tahun) dengan mengakses daftar perusahaan melalui www.sahamok.com dan mengakses data perusahaan berupa laporan tahunan dan laporan keuangan melalui www.idx.co.id. Objek penelitian ini adalah agresivitas pajak perusahaan pada perusahaan sektor pertambangan yang terdaftar di Bursa Efek Indonesia periode tahun 2012-2016. Agresivitas pajak pada perusahaan diduga dipengaruhi oleh beberapa faktor diantaranya yaitu, koneksi politik, capital intensity, profitabilitas, leverage dan ukuran perusahaan. Variabel dependen dalam penelitian ini yaitu Agresivitas Pajak (Y). Variabel independen dalam penelitian 
ini yaitu Koneksi Politik $\left(\mathrm{X}_{1}\right)$, Capital Intensity $\left(\mathrm{X}_{2}\right)$, Profitabilitas $\left(\mathrm{X}_{3}\right)$, Leverage $\left(\mathrm{X}_{4}\right)$, dan Ukuran Perusahaan $\left(\mathrm{X}_{5}\right)$.

Tindakan memanipulasi pendapatan kena pajak yang dilakukandengan perencanaan pajak baik secara legal (tax avoidance) maupun ilegal (tax evasion)merupakan agresivitas pajak. Pengukuran agresivitas pajak dalam penelitian ini menggunakan ETR. ETR dihitung dengan rumus yang digunakan Dyreng et al. (2008) yaitu.

$$
\mathrm{ETR}=\frac{\text { Beban Pajak Penghasilan }}{\text { Laba Sebelum Pajak }}
$$

Koneksi politik dalam penelitian ini menggunakan proksi ada atau tidaknya kepemilikan langsung (saham) pada perusahaan oleh pemerintah. Mengacu pada penelitian Adhikari et al. (2006). Pengukuran koneksi politik penelitian ini menggunakan variabel dummy, diberi nilai 1 apabila pada perusahaan terdapat kepemilikan saham dari pemerintah (BUMN) dan 0 apabila tidak ada. Pada penelitian pengukuran koneksi politik pada suatu perusahaan mengacu pada penelitian Lestari dan Putri (2017), dinilai dari adanya kepemilikan saham pemerintah minimal sebesar $25 \%$ yaitu sesuai dengan Undang-undang Nomor 36 Tahun 2008 Pasal 18 ayat 4 tentang hubungan istimewa. Kepemilikan saham minimal $25 \%$ oleh pemerintah mengindikasikan adanya koneksi politik.

Capital intensity adalah tindakan perusahaan yang menanamkan berinvestasi pada aset tetap. Capital intensity diukur menggunakan proksi yaitu membagi total aset tetap dengan total aset perusahaan. Rumus dari capital intensity yaitu.

$$
\text { CAPINT }=\frac{\text { Total Aset Tetap }}{\text { Total Aset }}
$$


Rasio profitabilitas menunjukkan kemampuan perusahaan dalam menghasilkan suatu laba dalam jangka pendek maupun jangka panjang. Apabila profitabilitas semakin tinggi maka seharusnya ETR suatu perusahaan juga semakin tinggi. Pengukuran profitabilitas dalam penelitian ini menggunakan rasio Return on Investment (ROI). Sartono (2010:123) merumuskan rasio ROI sebagai berikut.

ROI $=\frac{\text { Laba Setelah Pajak }}{\text { Total aset }}$

Untuk mengukur kemampuan utang baik jangka panjang maupun jangka pendek dalam membiayai aset perusahaan maupun operasional perusahaan maka digunakan rasio leverage.Leverage dihitung menggunakan rasioTotal Debt to Total Asset (DTA). Apabila rasio ini semakin tinggi maka semakin banyak utang yang digunakan perusahaan untuk menghasilkan laba. Leverage diukur menggunakan rumus sebagai berikut.

$$
\text { DTA }=\frac{\text { Total Utang }}{\text { Total Aset }}
$$

Ukuran perusahaan merupakan suatu pengklasifikasian sebuah perusahaan berdasarkan jumlah aset yang dimiliki oleh perusahaan. Penelitian ini menggunakan proxy total aset perusahaan untuk menentukan ukuranperusahaan.Ukuran perusahaan diukur dengan logaritma natural dari total aset.Rumus ukuran perusahaan menurut Lanis dan Richardson (2012) yaitu sebagai berikut. Ukuran perusahaan $=$ Ln Total Aset 


\section{HASIL DAN PEMBAHASAN}

Tabel 2.

Hasil Uji Statistik Deskriptif

\begin{tabular}{lrrrrr}
\hline & N & Minimum & Maximum & \multicolumn{1}{c}{ Mean } & Std. Deviation \\
\hline Koneksi Politik & 60 & 0 & 1 & 0,17 & 0,376 \\
Capital Intensity & 60 & 0,0550 & 0,7241 & 0,318813 & 0,1536772 \\
Profitabilitas & 60 & 0,0002 & 0,2897 & 0,081327 & 0,0603715 \\
Leverage & 60 & 0,1449 & 0,7969 & 0,419670 & 0,1574570 \\
Ukuran Perusahaan & 60 & 27,3861 & 32,1100 & 29,340978 & 1,3288760 \\
Agresivitas Pajak & 60 & 0,2279 & 0,6310 & 0,332132 & 0,0903393 \\
Valid N (listwise) & 60 & & & & \\
Sumber: data diolah, 2018 & & & &
\end{tabular}

Berdasarkan Tabel 2 dapat disimpulkan bahwa variabel bebas koneksi politik $\left(\mathrm{X}_{1}\right)$ memiliki nilai rata-rata sebesar 0,17 mendekati nilai minimum sebesar 0. Nilai standar deviasi dari koneksi politik sebesar 0,376. Variabel capital intensity $\left(\mathrm{X}_{2}\right)$ memiliki nilai rata-rata sebesar 0,318813 mendekati nilai maksimum sebesar 0,7241. Nilai minimum sebesar 0,0550 dan nilai standar deviasi dari capital intensity yaitu 0,1536772 . Profitabilitas $\left(\mathrm{X}_{3}\right)$ dengan nilai ratarata yaitu0,081327 mendekati nilai maksimum yaitu 0,2897 . Nilai minimum yaitu 0,0002 dan nilai standar deviasi dari profitabilitas yaitu 0,0603715. Variabel leverage $\left(\mathrm{X}_{4}\right)$ memiliki nilai rata-rata yaitu 0,419670 mendekati nilai maksimum yaitu 0,7969 . Nilai minimum yaitu 0,1449 dan nilai standar deviasi dari leverage yaitu 0,1574570 .Variabel ukuran perusahaan $\left(\mathrm{X}_{5}\right)$ memiliki nilai rata-rata yaitu 29,340978 mendekati nilai maksimum yaitu 32,1100. Nilai minimum yaitu 27,3861 dan nilai standar deviasi dari ukuran perusahaan yaitu1,3288760. Variabel terikat yaitu agresivitas pajak yang diproksikan dengan ETR pada perusahaan sektor pertambangan yang terdaftar di BEI tahun 2012-2016 rata-rata yaitu 0,332132 lebih mendekati nilai maksimumyaitu 0,6310 . Nilai minimum yaitu 0,2279 dan nilai standar deviasi yaitu 0,0903393. 
Hasil uji asumsi klasik ini disajikan sebagai berikut.

Tabel 3.

Rekapitulasi Hasil Uji Asumsi Klasik

\begin{tabular}{cccccc}
\hline \multirow{2}{*}{ Variabel } & Normalitas & Autokorelasi & \multicolumn{2}{c}{ Multikolinearitas } & Heteroskedastisitas \\
\cline { 2 - 6 } & $\begin{array}{c}\text { Asymp. Sig. } \\
\mathbf{2} \text { tailed }\end{array}$ & DW & Tolerance & VIF & Sig. \\
\hline Koneksi Politik & & & 0,883 & 1,132 & 0,274 \\
Capital Intensity & & & 0,871 & 1,148 & 0,127 \\
Profitabilitas & 0,483 & 2.015 & 0,793 & 1,261 & 0,076 \\
Leverage & & & 0,809 & 1,236 & 0,422 \\
Ukuran Perusahan & & & 0,854 & 1,171 & 0,556 \\
\hline
\end{tabular}

Sumber: Data diolah, 2018

Pada tabel 3 terlihat bahwa model regresi penelitian ini data berdistribusi normal, dengan nilai Asymp. Sig. (2-tailed) sebesar 0,483 lebih besar dari signifikansi 0,05. Hasil uji autokorelasi menunjukkan nilai Durbin Watson adalah 2.015, dan nilai DU adalah 1.7671 sehingga nilai 4-DU diperoleh yaitu 2.2329, maka berdasarkan syarat dari uji autokorelasi $\mathrm{DU}<\mathrm{DW}<4-\mathrm{DU}$ yaitu $1.7671<$ $2.015<2.2329$ artinya tidak mengandung gejala autokorelasi dan lolos uji autokorelasi. Hasil uji multikolinearitas menunjukkan bahwa semua variabel independen memiliki nilai tolerance $>0,10$ dengan nilai VIF $<10$ maka disimpulkan bahwa data penelitian terbebas dari multikolinearitas. Hasil uji heteroskedastisitas menunjukkan bahwa nilai signifikansi variabel bebas bernilai lebih besar dari tingkat signifikansi 0,05, menunjukkan tidak adanya gejala heteroskedastisitas dalam penelitian ini. Berdasarkan keempat uji asumsi klasik ini maka penelitian layak untuk dilanjutkan. 
Tabel 4.

Rekapitulasi dari Analisis Regresi Linear Berganda

\begin{tabular}{lrrrrc}
\hline \multicolumn{1}{c}{ Variabel } & $\begin{array}{c}\text { Koefisien } \\
\text { Regresi }\end{array}$ & \multicolumn{1}{c}{ Sig } & \multicolumn{1}{c}{ T } & Adjusted $\mathbf{R}^{\mathbf{2}}$ & F \\
\hline Koneksi politik & $-0,055$ & 0,059 & $-1,928$ & & \\
Capital Intensity & $-0,135$ & 0,058 & $-1,935$ & & \\
Profitabilitas & $-0,738$ & 0,000 & $-3,970$ & 0.278 & $0,000^{\mathrm{b}}$ \\
Leverage & 0,023 & 0,744 & 0,328 & & \\
Ukuran & 0,012 & 0,131 & 1,535 & & \\
Perusahaan & & & & &
\end{tabular}

Sumber: Data diolah, 2018

Berdasarkan hasil analisis regresi linier berganda seperti yang disajikan pada Tabel 4 maka dapat disusun persamaan regresi sebagai berikut.

$$
Y=0,068-0,055 X_{1}-0,135 X_{2}-0,738 X_{3}+0,023 X_{4}+0,012 X_{5}
$$

Persamaan regresi linier berganda menunjukkan bahwa arah masingmasing variabel koneksi politik, capital intensity, ptofitabilitas, leverage, dan ukuran perusahaan pada variabel agresivitas pajak apabila koefisien regresi dari variabel bebas menunjukkan tanda positif artinya memunyai pengaruh searah pada agresivitas pajak sedangkan apabila tandanya negatif maka memunyai pengaruh terbalik terhadap variabel bebas.

Nilai konstanta sebesar 0,068 memiliki arti jika nilai variabel independen sama dengan 0 , maka variabel dependen yaitu agresivitas pajak (Y) adalah sebesar 6,8 persen.Nilai koefisien regresi dari koneksi politik yaitu $-0,055$ berarti bahwa apabila koneksi politik pada perusahaan naik 1 persen maka agresivitas pajak akan menurun sebesar 5,5 persen dengan variabel independen lainnya dianggap konstan.Nilai koefisien regresi dari capital intensity yaitu -0,135 berarti bahwa apabila tingkat capital intensity perusahaan naik 1 persen maka agresivitas pajak akan menurun sebesar 13,5 persen dengan variabel independen lainnya dianggap konstan.Nilai koefisien regresi dari profitabilitas yaitu $-0,738$ berarti bahwa 
apabila tingkat profitabilitas perusahaan naik 1 persen maka agresivitas pajak akan menurunyaitu 73,8 persen dengan variabel independen lainnya dianggap konstan.Nilai koefisien regresi dari leverageyaitu 0,023 berarti bahwa apabila tingkat leverage perusahaaan naik 1 persen maka agresivitas pajak akan meningkat yaitu 2,3 persen dengan variabel independen lainnya dianggap konstan.Nilai koefisien regresi dari ukuran perusahaan yaitu 0,012 berarti bahwa apabila ukuran perusahaan naik 1 persen maka agresivitas pajak akan meningkat sebesar 1,2 persen dengan variabel independen lainnya dianggap konstan.

Hasil uji $\mathrm{F}$ mendapatkan hasil nilai $\mathrm{F}$ yaitu 5,549 dengan signifikansi yaitu 0,000 maka model penelitian ini layak karena nilai signifikan $<0,05$ yaitu 0,000 . Nilai adjusted $\mathrm{R}^{2}$ sebesar 0,278 memiliki arti bahwa 27,8 persen variasi dari variabel dependen, yaitu agresivitas pajak dipengaruhi oleh variasi dari variabel independen, yaitu koneksi politik, capital intensity, profitabilitas, leverage dan ukuran perusahaan, sedangkan sisanya sebesar 72,2 persen dipengaruhi faktorfaktor lainnya yang tidak jelaskan ke dalam model regresi.

Hipotesis pertama $\left(\mathrm{H}_{1}\right)$ menyatakan bahwa koneksi politik berpengaruh positif pada agresivitas pajak. Hasil pengujian diperoleh nilai statistik t sebesar 1,928 dengan nilai signifikansi 0,059. Nilai signifikansi lebih besar dibandingkan dengan taraf signifikansi 0,05 (nilai $0,059>0,05$ ) maka $\mathrm{H}_{1}$ ditolak. Hal ini menunjukkan bahwa variabel koneksi politik tidak berpengaruh pada agresivitas pajak.

Hasil penelitian ini sejalan dengan penelitian Dharma dan Ardiana (2016), Fatharani (2012), Fadila dkk. (2017) dan Lestari dan Putri (2017) yang 
membuktikan bahwa koneksi politik tidak berpengaruh terhadap agresivitas pajak. Zuhroh dan Sukmawati (2003) menyatakan bahwa perusahaan pertambangan merupakan salah satu contoh perusahaan yang termasuk dalam kelompok industri high profile. Perusahaan-perusahaan high profile, pada umumnya merupakan perusahaan yang memperoleh sorotan dari masyarakat karena aktivitas operasinya memiliki potensi untuk bersinggungan dengan kepentingan luas. Hal ini tentunya akan memotivasi perusahaan pertambangan selaku perusahaan high profile dan perusahaan BUMN untuk berusaha meningkatkan citra perusahaan dan menjadi tauladan bagi perusahaan lainnya, selain bertanggungjawab dengan lingkungan sekitar perusahaan juga akan menunjukkan bahwa mereka taat dalam membayar pajak demi pembangunan negara dan untuk memeroleh kepercayaan dari masyarakat, pemerintah selaku pemegang saham dan pemangku kepentingan lainnya. Fadila dkk. (2017) menyatakan bahwa perusahaan yang terindikasi mempunyai hubungan politik dengan pemerintah tidak memiliki tarif pajak efektif lebih rendah karena proses politik mengenai perpajakan tidak diterapkan ke dalam bentuk peraturan atau undang-undang yang memberikan secara langsung keringanan pajak.

Hipotesis kedua $\left(\mathrm{H}_{2}\right)$ menyatakan bahwa capital intensity berpengaruh positif pada agresivitas pajak. Hasil pengujian diperoleh nilai statistik t sebesar 1,935 dengan nilai signifikansi 0,058 . Nilai signifikansi lebih besar dari taraf signifikansi 0,05 atau nilai $0,058>0,05$ maka $\mathrm{H}_{2}$ ditolak. Hal ini menunjukkan bahwa variabel capital intensity tidak berpengaruh pada agresivitas pajak. 
Hasil penelitian ini sejalan dengan penelitian Putra dan Lely (2016), Ardyansah dan Zulaikha (2014), serta Adisamartha dan Naniek (2015). Perusahaan berinvestasi dengan aset tetap yang tinggi dengan tujuan untuk digunakan untuk operasional perusahaan dan investasi perusahaan bukan untuk aktivitas agresivitas pajak. Adisamartha dan Naniek (2015) menyatakan bahwa perusahaan tidak mampu memanfaatkan beban depresiasi untuk mengurangi laba bersih dengan tingginya aset tetap yang dimiliki perusahaan. Aset tetap perusahaan digunakan untuk kebutuhan operasional perusahaan, penggunaan aset tetap tersebut digunakan untuk membantu dan meningkatkan operasional perusahaan yang nantinya juga akanmenaikkan laba bersih perusahaan dibandingkan beban depresiasi dari aset tetap tersebut.

Hipotesis ketiga $\left(\mathrm{H}_{3}\right)$ menyatakan bahwa profitabilitas berpengaruh negatif pada agresivitas pajak. Hasil pengujian diperoleh nilai statistik t sebesar -3.970 dengan nilai signifikansi 0.000 . Nilai signifikansi lebih kecil dari taraf signifikansi 0,05 atau nilai $0,000<0,05$ maka $\mathrm{H}_{3}$ diterima. Variabel profitabilitas dengan nilai statistik $\mathrm{t}$ sebesar -3.970 bertanda negatif memperlihatkan bahwa variabel profitabilitas mempunyai hubungan terbalik dengan agresivitas pajak, sehingga dapat disimpulkan bahwa profitabilitasberpengaruh negatif pada agresivitas pajak.

Hasil penelitian ini sejalan dengan penelitian Gupta dan Newberry (1997), Utari dan Supadmi (2017), Prasista dan Ery (2016), Maharani dan Suardana (2014) serta Ariawan dan Setiawan (2017) menemukan bahwa profitabilitas berpengaruh negatif pada agresivitas pajak. Wajib pajak yang berpenghasilan besar akancenderung untuk patuh dan taat apabila dibandingkan dengan wajib 
pajak yang memiliki penghasilan rendah, hal ini karena wajib pajak yang memiliki penghasilan yang besar cenderung lebih konservatis dalam pelaporan kewajiban perpajakannya. Apabila sistem administrasi otoritas perpajakan pada suatu negara lemah (tidak dapat mengawasi kepatuhan substansi pembayaran pajak dari wajib pajak), maka akan mendorong wajib pajak tersebut menjadi tidak patuh karena melihat adanya peluang-peluang yang bisa dimanfaatkan. Penerapan tarif pajak yang rendah juga akan memotivasi kepatuhan wajib pajak hal ini karena jumlah kewajiban pembayaran pajak tidak memberatkan pihak wajib pajak. Disamping semua itu wajib pajak juga berasumsi bahwa jumlah pajak yang dibayarkan merupakan kewajiban dan wajar karena pemerintah telah menyediakan berbagai fasilitas umum yang diperlukan dalam menggerakkan perekonomian suatu negara (pajak.go.id, 2012).

Hipotesis keempat $\left(\mathrm{H}_{4}\right)$ menyatakan bahwa leverage berpengaruh negatif pada agresivitas pajak. Hasil pengujian diperoleh nilai statistik t sebesar 0,328 dengan nilai signifikansi 0,744 . Nilai signifikansi lebih besar dari taraf signifikansi 0,05 atau nilai 0,744 >0,05 maka $\mathrm{H}_{4}$ ditolak. Hal ini menunjukkan bahwa variabel leverage tidak berpengaruh pada agresivitas pajak.

Hasil penelitian ini sejalan dengan penelitian Putra dan Lely (2016), Gemilang (2017), Ardyansyah dan Zulaikha (2014), serta Adisamartha dan Naniek (2015). Hal ini menunjukkan bahwa kebijakan pendanaan yang menggunakan utang atau dana pihak ketiga untuk membiayai operasi perusahaan tidak memengaruhi indikasi tindakan agresivitas pajak yang akan dilakukan suatu perusahaan. Adisamartha dan Naniek (2015) menyatakan tidak berpengaruhnya 
leverage dikarenakan perusahaan yang memiliki tingkat leverage tinggi tidak dapat memanfaatkan beban bunga yang ditanggungnya untuk mengurangi laba bersih, karena perusahaan harus memertahankan laba mereka pada kondisi yang baik. Hal ini tidak mendukung teori akuntansi positif khususnya biaya politik dan hipotesis ekuitas utang.

Hipotesis kelima $\left(\mathrm{H}_{5}\right)$ menyatakan bahwa ukuran perusahaan berpengaruh positif pada agresivitas pajak. Hasil pengujian diperoleh nilai statistik t sebesar 1,535 dengan nilai signifikansi 0,131 . Nilai signifikansi lebih besar dari taraf signifikansi 0,05 atau nilai 0,131>0,05 maka $\mathrm{H}_{5}$ ditolak. Hal ini menunjukkan bahwa variabel ukuran perusahaan tidak berpengaruh pada agresivitas pajak.

Hasil penelitian ini sejalan dengan penelitian Dewi dan Jati (2014), Nugraha (2015) dan Gemilang (2017). Nugraha (2015) berpendapat bahwa ukuran perusahaan tidak berpengaruh pada agresivitas pajak karena perusahaan besar akan berusaha menjaga citra perusahaan. Dewi dan Jati (2014) menyatakan bahwa tidak berpengaruhnya variabel ini disebabkan karena membayar pajak merupakan kewajiban perusahaan. Perusahaan besar ataupun perusahaan kecil pasti akan selalu dikejar oleh fiskus apabila melanggar ketentuan perpajakan. Disamping itu, perusahaan besar akanmenjadi sorotan serta mendapat perhatian pemerintah terkait laba bersih yang diperoleh, sehingga mereka sering menarik perhatian fiskus untuk dikenai pajak yang sesuai dengan aturan yang berlaku.

\section{SIMPULAN}

Berdasarkan hasil penelitian yang diperoleh melalui pengujian statistik serta pembahasan seperti yang telah dipaparkan di bab sebelumnya, maka dapat 
disimpulkan bahwa variabel profitabilitas berpengaruh negatif pada agresivitas pajak. Variabel koneksi politik, capital intensity, leverage dan ukuran perusahaan tidak berpengaruh pada agresivitas pajak.

Berdasarkan hasil pembahasan dan simpulan maka saran yang dapat diberikan dalam penelitian ini yaitu bagi pemerintah diharapkan dapat memertimbangkan variabel-variabel yang diduga memengaruhi agresivitas pajak dalam menentukan kebijakan-kebijakan terkait peraturan perpajakan. Bagi investor disarankan untuk berhati-hati sebelum berinvestasi dan memerhatikan profit perusahaan serta kemungkinan perusahaan untuk melakukan agresivitas pajak melalui cara-cara di luar dari variabel pada penelitian ini. Bagi penelitian selanjutnya disarankan untuk memperluas ruang lingkup penelitian yang tidak hanya pada perusahaan sektor pertambangan namun juga pada perusahaan sektor lainnya. Penelitian selanjutnya juga disarankan untuk melakukan perluasan penelitian dengan menambah atau mengganti beberapa variabel yang dimungkinkan memengaruhi tindakan agresivitas pajak serta menggunakan proksi pengukuran yang berbeda dari variabel-variabel dalam penelitian ini, karena nilai koefisien determinasi $\left(\mathrm{R}^{2}\right)$ sebesar 27,8 persen menunjukkan hanya 27,8 persen variasi variabel bebas yang mempengaruhi variabel terikat.

\section{REFERENSI}

Adhikari Ajay, Chek Derashid dan Hao Zhang. 2006. Public Policy, Political Connections and Effective Tax Rates: Longitudinal Evidence from Malaysia. Journal of Accounting and Public Policy, 25, pp. 574-995.

Adisamartha, Ida Bagus Putu Fajar dan Naniek Noviari. 2015. Pengaruh Likuiditas, Leverage, Intensitas Persediaan dan Intensitas Aset Tetap Pada Tingkat Agresivitas Wajib Pajak Badan. E-jurnal Akuntansi Universitas Udayana, 13(3), hal.973-1000. 
Andhari, Putu Ayu Seri dan I Made Sukartha. 2017. Pengaruh Pengungkapan Corporate Social Responsibility, Profitabilitas, Inventory Intensity, Capital Intensity dan Leverage Pada Agresivitas Pajak. E-jurnal Akuntansi Universitas Udayana, 18(3), hal. 2115-2142.

Ardyansah, Danis dan Hj. Zulaikha.2014. Pengaruh Size, Leverage, Profitability, Capital Intensity Ratio dan Komisaris Independen Terhadap Effective Tax Rate (ETR) (Studi Empiris Pada Perusahaan Manufaktur yang Terdaftar di BEI Selama Periode 2010-2012). Skripsi Sarjana Fakultas Ekonomika dan BisnisUniversitas Diponegoro, Semarang.

Ariawan, I Made Agus Riko dan Putu Ery Setiawan. 2017. Pengaruh Dewan Komisaris Independen, Kepemilikan Institusional, Profitabilitas dan Levergae Terhadap Tax Avoidance. E-jurnal Akuntansi Universitas Udayana, 18(3), hal.1831-1859.

Biro Analisa Anggaran dan Pelaksanaan APBN. 2013. Evaluasi Rendahnya Realisasi Pendapatan Negara 2013. www.dpr.go.id/doksetjen/dokumen/apbn_EVALUASI_RENDAHNYA_REALI SASI_PENDAPATAN_NEGARA_TAHUN_201320140821142652.pdf. Diakses pada 2 januari 2018.

Chaney, P. K., Mara Faccio dan David Parsley. 2007. The Quality of Accounting Information in Politically Connected Firms. Krannert Graduate School of Management.Purdue University.

Chariri, A. 2008. Kritik Sosial Atas Pemakaian Teori dalam Penelitian Pengungkapan Sosial dan Lingkungan. Jurnal Maksi, 8 (2), 151- 169.

Dewi, Ayu Aryista dan Luh Gede Krisna Dewi. 2017. Transparasi Informasi Memoderasi Pengaruh Agresivitas Pajak Pada Nilai Perusahaan Pertambangan di Bursa Efek Indonesia. Jurnal Ilmu Akuntansi, 10 (2), hal. 211-230.

Dewi, Ni Nyoman Kristiana dan I Ketut Jati. 2014. Pengaruh Karakter Eksekutif, Karakteristik Perusahaan, dan Dimensi Tata Kelola Perusahaan yang Baik pada Tax Avoidance di Bursa Efek Indonesia. E-jurnal Akuntansi Universitas Udayana, 6 (2), hal.249-260.

Direktorat Jenderal Pajak (Kementerian Keuangan). 2012. Strategi Meningkatkan Kepatuhan Wajib Pajak.http://www.pajak.go.id/content/strategimeningkatkan-kepatuhan-wajib-pajak/Diakses pada 12Januari 2018.

Dharma, I Made Surya dan Putu Agus Ardiana. 2015. Pengaruh Leverage, Intensitas Aset Tetap, Ukuran Perusahaan, dan Koneksi Politik Terhadap 
Tax Avoidance. E-jurnal Akuntansi Universitas Udayana, 15 (1), hal.584613.

Dyreng, Scott D., Michelle Hanlon, Edward L. Maydew. 2008. Long Run Corporate Tax Avoidance. The Accounting Review, 83(1), pp.61-82.

D. Putri, Dea Ardana. 2016. Pengaruh Firm Size dan Debt to Equity Ratio Terhadap profitabilitas Perusahaan dengan Tanggung Jawab Sosial Perusahaan Sebagai Variabel Mediasi (Studi Empiris pada Perusahaan Pertambangan yang Terdaftar di BEI Tahun 2012-2014). Skripsi. Fakultas Ekonomi Universitas Islam Indonesia, Yogyakarta.

Faccio, M. 2010. Differences between Politically Connected and Nonconnected Firms: A Cross-Country Analysis. Financial Management, 39(3), pp. 905928.

Fadila, Melisa, M. Rasuli dan Rusli. 2017. Pengaruh Return On Asset, Leverage, Ukuran Perusahaan Kompensasi Rugi Fiskal, Kepemilikan Institusional, dan Koneksi Politik Terhadap Penghindaran Pajak (Studi Empiris pada Perusahaan Manufaktur yang Terdaftar di BEI Tahun 2011-2015). JOM Fekon, 4 (1), hal.1671-1684.

Fatayatiningrum, Desie. 2011. Analisis Pengaruh Manajemen Laba dan Mekanisme Corporate Governance Terhadap Corporate Environmental Disclosure (Studi Empiris pada Perusahaan yang Terdaftar di BEI Tahun 2008-2009). Skripsi. Sarjana Jurusan Akuntansi Fakultas Ekonomi Universitas Diponegoro, Semarang.

Fatharani, Nazhaira. 2012. Pengaruh Karaketeristik Kepemilikan, Reformasi Perpajakan, dan Hubungan Politik Terhadap Tindakan Pajak Agresif. Skripsi. Fakultas Ekonomi Program Studi Akuntansi Universitas Indonesia.

Frank, M., Lynch, L., dan Rego, S. 2009. Tax Reporting Aggressiveness and Its Relation to Aggressive Financial Reporting.The Accounting Review, 84, pp. 467-496.

Gemilang, Dewi Nawang. 2017. Pengaruh Likuiditas, Leverage, Profitabilitas, UkuranPerusahaan dan Capital IntensityTerhadap Agresivitas Pajak Perusahaan (Studi Empiris Pada Perusahaan Property dan Real Estate Yang Terdaftar di BEI Pada Tahun 2013-2015).Skripsi. Jurusan Akuntansi Syariah Fakultas Ekonomi dan Bisnis Islam Institut Agama Islam Negeri Surakarta. Surakarta.

Gupta, Sanjay dan Kaye Newberry. 1997. Determinants of the Variability in Corporate Effective Tax Rates: Evidence from Longitudinal Data. Journal of Accounting and Public Policy, 16, pp.1-34. 
Hasibuan, Abdul Nasser. 2009. Pengaruh Karakteristik Perusahaan dan Ekonomi Makro Terhadap Return Saham LQ-45 di Bursa Efek Indonesia.Tesis Program Studi Ilmu Akuntansi Sekolah Pascasarjana Universitas Sumatera Utara.

Ikatan Akuntan Indonesia (IAI). 2015. Standar Akuntansi Keuangan (SAK) per 1 Januari 2015. Jakarta: Ikatan Akuntansi Indonesia.

Indonesia Stock Exchange (IDX) Bursa Efek Indonesia. 2017. Laporan Keuangan \& Tahunan. www.idx.co.id. Diakses 18 Mei 2017.

Kementerian Keuangan Republik Indonesia. 2015. Realisasi Pendapatan Negara Tahun 2014 Capai Rp1.537,2 Triliun.https://www.kemenkeu.go.id. Diakses 11 Oktober 2017.

Kementerian Keuangan Republik Indonesia. 2016. Realisasi Pendapatan Negara 2015 Capai Rp1.491,5 Triliun. https://www.kemenkeu.go.id. Diakses 11 Oktober 2017.

Kementerian Keuangan Republik Indonesia. 2016. Pemerintah Soroti Rendahnya Kepatuhan Wajib Pajak Minerba dan Migas. https://www.kemenkeu.go.id/publikasi/berita/pemerintah-soroti-rendahnyakepatuhan-wajib-pajak-minerba-dan-migas/Diakses 5 februari 2018.

Kementerian Keuangan Republik Indonesia. 2017. Amnesti Pajak Sumbang Rp107 Triliun bagi Pertumbuhan Penerimaan Pajak. https://www.kemenkeu.go.id. Diakses 11 Oktober 2017.

Kim, Chansog (Francis) dan Liandong Zhang. 2013. Corporate Political Connections and Tax Aggressiveness. Working Paper.City University of Hong Kong.

Lesmana, I Putu Adi Surya. 2016. Pengaruh Manajemen Laba Pada Nilai Perusahaan (Studi Pada Perusahaan Manufaktur yang Terdaftar di Bursa Efek Indonesia Tahun 2012-2015). Skripsi Sarjana Jurusan Akuntansi Fakultas Ekonomi dan Bisnis Universitas Udayana, Bali.

Lestari, Gusti Ayu Widya dan I.G.A.M Asri Dwija Putri. 2017. Pengaruh Corporate Governance, Koneksi Politik, dan Leverage Terhadap Penghindaran Pajak. E-jurnal Akuntansi Universitas Udayana, 18 (3), hal.2028-2054.

Leuz, C., dan Oberholzer-Gee, F. 2006. Political Relationships, Global Financing, And Corporate Transparency: Evidence From Indonesia. Journal of Financial Economics, 81 (2), pp. 411-439. 
Maharani, I Gusti Ayu Cahya dan Ketut Alit Suardana. 2014. Pengaruh Corporate Governance, Profitabilitas dan Karakteristik Eksekutif pada Tax Avoidance Perusahaan Manufaktur. E-jurnal Akuntansi Universitas Udayana, 9 (2), hal.525-539.

Mardiasmo. 2016. Perpajakan Edisi Terbaru 2016. Yogyakarta: Penerbit Andi.

Mustika, Vince Ratnawati dan Alfiati Silfi. 2017. Pengaruh Corporate Social Responsibility, Ukuran Perusahaan, Profitabilitas, Leverage, Capital Intensity dan Kepemilikan Keluarga Terhadap Agresivitas Pajak (Studi Empiris Pada Perusahaan Pertambangan dan Pertanian Yang Terdaftar Di Bursa Efek Indonesia Periode Tahun 2012-2014). JOM Fekon, 4 (1).

Muzakki, Muadz Rizki. 2015. Pengaruh Corporate Social Responsibility dan Capital Intensity Terhadap Penghindaran Pajak (Studi Empiris pada Perusahaan Manufaktur yang Terdaftar Pada Bursa Efek Indonesia Tahun 2011-2013). Skripsi Fakultas Ekonomika dan Bisnis Universitas Diponegoro, Semarang.

Nugraha, Novia Bani. 2015. Pengaruh Corporate Social Responsibility, Ukuran Perusahaan, Profitabilitas, Leverage dan Capital Intensity Terhadap Agresivitas Pajak (Studi Empiris pada Perusahaan Non-Keuangan yang Terdaftar di BEI Selama Periode 2012-2013). Skripsi Fakultas Ekonomika dan Bisnis. Universitas Diponegoro, Semarang.

Prasista, Putu Meita dan Ery Setiawan. 2016. Pengaruh Profitabilitas dan Pengungkapan Corporate Social Responsibility terhadap Agresivitas Pajak Penghasilan Wajib Pajak Badan. E-jurnal Akuntansi Universitas Udayana, 17 (3), hal.2120-2144.

Purwoto, Lukas. 2011. Pengaruh Koneksi Politis, Kepemilikan Pemerintah dan Keburaman Laporan Keuangan terhadap Kesinkronan dan Risiko Crash Harga Saham.Ringkasan Disertasi Program Doktor Ilmu Ekonomi Manajemen Universitas Gadjah Mada, Yogyakarta.

Putra, I Gusti Lanang Ngr. Dwi Cahyadi dan Ni Ketut Lely Aryani Merkusiwati. 2016. Pengaruh Komisaris Independen, Leverage, Size, dan Capital Intensity Ratio Pada Tax Avoidance. E-jurnal Akuntansi Universitas Udayana, 17 (1), hal. 690-714.

Rahayu, Miryati Putri dan Jaka Darmawan. 2017. Pengaruh Agresivitas Pajak Terhadap Corporate Social Responsibility. Semnas IIB Darmajaya, Hal. 541-558. 
Richardson, Grant dan Roman Lanis. 2007. Determinants of The Variability in Corporate Effective Tax Rates and Tax Reform: Evidence from Australia. Journal of Accounting and Public Policy, 26 (6), pp. 689-704.

Richardson, Grant dan Roman Lanis. 2012. Corporate social responsibility and tax aggressiveness:An empirical analysis. Journal of Accounting and Public Policy, 31, pp. 86-108.

Rodriguez, E., F. dan M. Arias. 2012. Do Business Characteristics Determine an Effective Tax Rate? The Chinese Economy, 45(6).

Saham OK. 2017. Perusahaan Pertambangan di Indonesia. https://www.sahamok.com/Diakses 18 Mei 2017.

Sartono, Agus R. 2010. Manajemen Keuangan (Teori dan Aplikasi), Edisi 4. Yogyakarta: BPFE-Yogyakarta.

Siregar, Rifka dan Dini Widyawati. 2016. Pengaruh Karakteristik Perusahaan Terhadap Penghindaran Pajak pada Perusahaan Manufaktur di BEI. Jurnal Ilmu dan Riset Akuntansi, 5 (2).

Suandy, Erly. 2011. Perencanaan Pajak, Edisi 5. Jakarta: Salemba Empat.

Undang-Undang Republik Indonesia Nomor 36 Tahun 2008. Lembaran Negara Republik Indonesia Tahun 2008 Nomor 133. Jakarta.

Utari, Ni Kadek Yuliani dan Ni Luh Supadmi. 2017. Pengaruh Corporate Governance, Profitabilitas dan Koneksi Politik Pada Tax Avoidance. EJurnal Akuntansi Universitas Udayana, 18 (3), hal.2202-2230.

Watts, R.L., dan Zimmerman, J.L. 1986. Towards a Positive Theory of Accounting. New Jersey: Prentice-Hall.

Watts, R. L., \& Zimmerman, J. L. 1990. Positive Accounting Theory: A Ten Year Perspective. The Accounting Review, 65(1), pp. 131-156.

Wiagustini, Ni Luh Putu. 2014. Dasar-dasarManajemen Keuangan. Cetakan Pertama. Denpasar: Udayana University Press.

Zuhroh, Diana dan I Putu Pande Heri Sukmawati. 2003. Analisis Pengaruh Luas Pengungkapan Sosial Dalam Laporan Tahunan Perusahaan Terhadap Reaksi Investor (Studi Kasus Pada Perusahaan-Perusahaan High Profile di BEJ). Simposium Nasional Akuntansi VI, hal. 1314-1341. 